\title{
CORRELATIONS BETWEEN GROWTH VARIABLES AND THE DICKSON QUALITY INDEX IN FOREST SEEDLINGS
}

\author{
Alexandre Francisco Binotto ${ }^{1}$, Alessandro Dal' Col Lúcio², Sidinei José Lopes²
}

(received: August 26, 2009; accepted: July 29, 2010)

\begin{abstract}
This study aims to identify correlations between growth variables and the Dickson quality index in seedlings of Eucalyptus grandis and Pinus elliottii var. elliottii. The experiment was conducted in a greenhouse and the following variables were observed: stem base diameter, shoot height, number of leaves, leaf dry matter, stem base dry matter, root dry matter, shoot dry matter, total dry matter, ratio of shoot dry matter to root dry matter and ratio of shoot height to stem base diameter in E. grandis 60 , 75, 90, 105 and 120 days after seedling emergence, and in P. elliottii 25, 50, 75, 100, 125, 150 and 175 days after seedling emergence. Using Pearson correlation and also path and regression analyses, correlations were analyzed between observed variables according to day after emergence and the Dickson quality index. Stem base diameter was found to have stronger correlation with days after emergence in comparison to shoot height, in both species. Root dry matter was found to have stronger correlation with the Dickson quality index. Stem base diameter was the most suitable parameter to indicate seedling quality due to its higher correlation level with the Dickson quality index. Shoot height was only effective to indicate seedling quality if analyzed together with stem base diameter. Variables relating to dry matter showed the highest correlations with the Dickson quality index (DQI), followed by stem base diameter. Conversely, number of leaves showed the poorest correlations with DQI, followed by seedling height.
\end{abstract}

Key words: Eucalyptus grandis, Pinus elliottii, path analysis, regression analysis, linear correlation.

\section{RELAÇÕES ENTRE VARIÁVEIS DE CRESCIMENTO E O ÍNDICE DE QUALIDADE DE DICKSON EM MUDAS FLORESTAIS}

RESUMO: Neste estudo, objetivou-se identificar a relação entre variáveis de crescimento e o Índice de Qualidade de Dickson, em mudas de Eucalyptus grandis e Pinus elliottii var. elliottii. $O$ trabalho foi realizado em casa de vegetação, com as observações das variáveis diâmtero de colo, altura da parte aérea, número de folhas, fitomassas secas de folhas, do colo, do sistema radicular, da parte aérea e total, as relações da fitomassa seca da parte aérea/ fitomassa seca do sistema radicular e da altura da parte aéreal diâmtero de colo em E. grandis aos 60, 75, 90, 105 e 120 dias e em P. elliottii aos 25, 50, 75, 100, 125, 150 e 175 dias após emergência das mudas. Pela correlação de Pearson, análises de trilha e de regressão, avaliaram-se as relações entre as variáveis observadas com os dias após a emergência e o índice de qualidade de Dickson. O diâmtero de colo apresentou maior relação com os dias após emergência, quando comparado com a altura da parte aérea, para ambas as espécies estudadas. A fitomassa seca de raiz esteve mais correlacionada com o índice de qualidade de Dickson. O diâmtero de colo foi mais propício para indicar qualidade de muda, em razão do seu maior grau de relação com índice de qualidade de Dickson. A variável altura da parte aérea só se apresentou eficiente para indicar qualidade de mudas, quando analisada juntamente com o diâmtero de colo. As fitomassas secas são as variáveis com maiores relações com o Índice de Qualidade de Dickson (IQD), seguidas do diâmtero de colo. Já, o número de folhas, seguido da altura da muda, são as com menores relações com o IQD.

Palavras-chave: Eucalyptus grandis, Pinus elliottii, análise de trilha, regressão, correlação linear.

\section{INTRODUCTION}

Production of forest seedlings is one of the most important stages in the establishment of forest stands as it strongly affects forest yield. A successful, high yielding stand is closely dependent on the quality of planted seedlings, which should be capable of resisting adverse field conditions and grow into trees with an economically desirable volume (GOMES et al. 2002). One of the problems faced by producers of forest seedlings involves being able to pinpoint characteristics with which to anticipate seedling size and performance in the field. This type of analysis, according to Reis et al. (2008a), is often intuitive and lacks an appropriate definition to explain seedling survival and growth requirements. Therefore, understanding existing correlations between morphological parameters is key to

${ }^{1}$ Forest Engineer, M.Sc. in Forest Engineering - Rua Pinheiro Machado, 2755/41, São Pelegrino - $95020-172$ - Caxias do Sul, RS alexandrebinotto@hotmail.com

${ }^{2}$ Agronomist Engineer, Dr. Professor of Agronomy (Plant Production) - Departamento de Fitotecnia - Centro de Ciências Rurais Universidade Federal de Santa Maria - Campus Universitário, Camobí - 97105-900 - Santa Maria, RS - adlucio@smail.ufsm.br, sjlopes@smail.ufsm.br 
identifying the best production methods and planting seasons to ensure good quality seedlings (REIS et al. 2008b).

Several variables are used to evaluate seedling quality, including shoot height, root configuration, stem base diameter, ratio of shoot to root, ratio of stem base diameter to shoot height, dry and fresh matter weight of shoot and root, shoot stiffness and nutritional aspects (PAIVA \& GOMES 1993).

The correlation between seedling height and shoot dry matter weight is an element to consider, due to their good relative contribution toward the seedling quality pattern (GOMES et al. 2002). These authors report that the lower the ratio of height to shoot dry matter weight, the more lignified the seedling and the greater its field survival capability. Wendling et al. (2005) demonstrated that rating seedlings according to height class has been widely used in commercial nurseries, facilitating fertilization and irrigation management, particularly to stimulate the growth of smaller seedlings. However, Fonseca et al. (2002) argue that variables used for evaluating seedling quality should not be studied separately, that way avoiding the risk of selecting higher and yet weaker seedlings while discarding smaller, sturdier ones.

The Dickson quality index - DQI (DICKSON et al. 1960) is a tool to evaluate seedling quality as a function of total dry matter (TDM), shoot height (SH), stem base diameter (SBD), shoot dry matter (SDM) - sum of stem base dry matter and leaf dry matter - and root dry matter $(\mathrm{RDM})$, and is given by the expression:

$$
\mathrm{DQI}=\frac{\mathrm{TDM}(\mathrm{g})}{\frac{\mathrm{SH}(\mathrm{cm})}{\mathrm{SBD}(\mathrm{mm})}+\frac{\mathrm{SDM}(\mathrm{g})}{\mathrm{RDM}(\mathrm{g})}}
$$

DQI is considered a promising integrated measure of morphological traits (JOHNSON \& CLINE 1991) and thought to be a good indicator of seedling quality as its calculation computes robustness and biomass distribution while considering several important parameters (FONSECA et al. 2002).

Given the above, this work aims to identify the relationship between morphological growth variables and the Dickson quality index so as to predict seedling quality in Eucalyptus grandis and Pinus elliottii.

\section{MATERIAL AND METHODS}

This work was conducted in a temperaturecontrolled greenhouse 6 X $30 \mathrm{~m}$ in size and located in the
Rural Sciences Center of the Federal University of Santa Maria (CCR-UFSM) at latitude $29^{\circ} 43^{\prime} 14.51^{\prime}$ ' south and longitude $53^{\circ} 43^{\prime} 18.47^{\prime \prime}$ 'west, at an altitude of 93m. Seedlings of Eucalyptus grandis W. Hill ex Maid. and Pinus elliottii var. elliottii - Engelm were used, produced in T53/4 polypropylene tubes $125 \mathrm{~mm}$ in height, $12 \mathrm{~mm}$ in upper-end diameter, with a capacity of $53 \mathrm{~cm}^{3}$. Seeds of $E$. grandis were provided by Santa Maria Forest Nursery, as obtained from lot EGR24 of the Seed Production Area (SPA) of Horto Florestal da Estância, a property owned by Riocell-Guaíba/ RS - known today as Aracruz Celulose. Seeds of P. elliottii were also provided by Santa Maria Forest Nursery, as obtained from plot T31/lot CB14 of a Seed Production Area (SPA) of the Forest Research and Studies Institute (Seeds Division: Production, Technology and Commercialization of Forest Seeds), in Capão Bonito (SP). The substrate used for $E$. grandis was Plantmax ${ }^{\circledR}$ and the substrate used for $P$. elliottii was peat, with nutrient adjustments, applying 2.30 $\mathrm{g}$ of urea after each seedling measurement.

The experiment consisted of two trays containing 224 seedlings of eucalyptus and two trays containing 233 seedlings of pine. Evaluations of $E$. grandis were made 60, $75,90,105$ and 120 days after the emergence of plant embryos (DAE), while evaluations of $P$. elliottii were made $25,50,75,100,125,150$ and 175 days after embryo emergence. In each evaluation, 32 seedlings of $E$. grandis and 24 seedlings of $P$. elliottii were sampled in tray 1 - the tray with varied competition, that is, rearranging the remaining seedlings in order to verify their behavior under conditions of improved light and aeration.

Assessed variables included stem base diameter $(\mathrm{mm})$, shoot height $(\mathrm{cm})$, number of leaves (NL), leaf dry matter (LDM), stem base dry matter (SBDM), root dry matter (RDM), shoot dry matter (SDM), total dry matter (TDM), ratio of shoot to root (RSR), ratio of shoot height to stem base diameter (RHD) and Dickson quality index (DQI). To obtain dry matters, each component (leaves, stem base, roots) were placed separately in paper bags and oven dried at $75^{\circ}$ to $80^{\circ} \mathrm{C}$ for $72 \mathrm{~h}$, with values expressed as $\mathrm{g}$ plant $^{-1}$. After each data collection, remaining seedlings in tray 1 were rearranged so as to verify the influence of improved light and aeration conditions on seedlings. In tray 2 - the tray with full competition, that is, with no seedling removal-, also containing 224 and 233 seedlings of $E$. grandis and $P$. elliottii respectively, assessed variables included stem base diameter (SBD in $\mathrm{mm}$ ), shoot height $(\mathrm{SH}$ in $\mathrm{cm}$ ) and number of leaves (NL), selecting the same number of seedlings as in tray 1 .

Cerne, Lavras, v. 16, n. 4, p. 457-464, out./dez. 2010 
The Pearson linear correlation analysis was applied between all observed variables, and correlation coefficients were broken down into direct and indirect effects through path analysis (CRUZ \& CARNEIRO 2003), with DQI set as dependent variable.

A multiple linear regression analysis of DQI was conducted as a function of independent variables shoot height, stem base diameter and days after emergence. For E. grandis, number of leaves was also used as an independent variable. A simple linear regression analysis was also conducted, always computing days after emergence as independent variable, in full and varied competition. These analyses enable identifying, among non-destructive testing variables, those with stronger correlations with DQI and days after emergence, allowing estimations of seedling quality on the basis of time spent in the nursery.

To select the best regression models, higher adjusted coefficient of determination ( $R^{2} a j$ ), lower coefficient of variation (CV\%) and lower mean standard error (Syx) criteria were used. A 5\% probability level was adopted in all statistical analyses.

\section{RESULTS AND DISCUSSION}

All correlation coefficients were positive and significant (Table 1). In Pinus elliottii, variable height showed a higher correlation with other variables in comparison to Eucalyptus grandis. Variable number of leaves in E. grandis showed lower correlation coefficients, demonstrating a degree of unreliability in using it as an indicator of seedling quality. Root dry matter proved highly correlated with DQI, DAE, SBD, TDM, SBDM and LDM, in both species. According to Hermann (1964), root dry matter is acknowledged to be one of the best and most important variables for determination of survival and establishment of field seedlings, validating the significant relationship obtained in this study.

While studying seedlings of Schinus terebinthifolius Raddi, José et al. (2005) observed that root growth potential was significantly correlated with stem base diameter, agreeing with results obtained here, where stem base diameter was the variable most strongly correlated with the others, a result also shared by Johnson \& Cline (1991).

Ratio of shoot dry matter to root dry matter can be considered an effective, safe index to evaluate seedling quality, as described by Parviainem (1981), as that correlation was found positive and significant (Table 1) upon analysis of the Pearson correlation coefficient for SBDM and LDM with RDM.

Stem base diameter was found to be strongly correlated with all parameters, along with root dry matter, both in E. grandis and in P. elliottii. In fact, the architecture of the root system directly influences seedlings in that the greater the root area for nutrient absorption, the more positive the growth behavior. Thus stem base diameter along with root dry matter come as key morphological variables for determination of seedling quality, higher values corresponding to increased root volume, a result also shared by Daniel et al. (1997) with seedlings of Acacia mangium.

Significant correlations were found between the Dickson quality index (DQI) and variables height, stem base diameter and days after emergence, indicating a satisfactory outcome due to the fact that the assessment of these variables has a non-destructive nature and thus facilitates and enables experimentation in forest nurseries. While studying seedling quality in Trema micrantha (L.) Blume, Fonseca et al. (2002) reported that DQI is highly correlated with all morphological parameters, agreeing with results in this study. Table 1 shows a tendency toward higher correlation coefficients for $P$. elliottii than for $E$. grandis, with special mention of DAE and SBD.

The degree of multicollinearity was considered weak, despite the significant correlations, allowing the use of all variables. Irrespective of the species, RDM followed by LDM showed the strongest direct effects while other variables, the strongest indirect effects, affecting estimations of direct effects with DQI (Table 2). This behavior demonstrates that in reality these variables are the true indicators of seedling quality.

Correlations of RDM and LDM with height and stem base diameter are of extreme importance. With these positive significant correlations it can be said that height and stem base diameter are indicators of RDM and LDM estimations.

The above statement is based on Table 3 results, where higher scoring equations, thus indicating better estimations, were those having height and stem base diameter as independent variables (equations E6, E1, E5 and E2 for E. grandis, and P3, P2, P7 and P5 for P. elliottii).

Days after emergence (DAE) was another very important variable in high scoring equations, showing that throughout the seedling cycle there is an increase in the values of all other variables and, consequently, in seedling quality. As regards E. grandis, equation E2 came fourth

Cerne, Lavras, v. 16, n. 4, p. 457-464, out./dez. 2010 
Table 1 - Pearson correlation coefficients among Dickson quality index (DQI) and other observed variables in seedlings of Eucalyptus grandis and Pinus elliottii. Santa Maria, RS, 2009.

Tabela 1 - Coeficientes de correlação de Pearson entre índice de qualidade de Dickson (DQI) e as demais variáveis observadas em mudas de Eucalyptus grandis e Pinus elliottii. Santa Maria, RS, 2009.

\begin{tabular}{|c|c|c|c|}
\hline & & Eucalyptus grandis & Pinus elliottii \\
\hline \multirow{8}{*}{ DQI versus } & DAE & 0.7958 & 0.8455 \\
\hline & SH & 0.6557 & 0.7072 \\
\hline & SBD & 0.8780 & 0.8497 \\
\hline & NL & 0.3902 & --- \\
\hline & SBDM & 0.8818 & 0.8279 \\
\hline & LDM & 0.8862 & 0.8674 \\
\hline & $\mathrm{RDM}$ & 0.9677 & 0.9934 \\
\hline & TDM & 0.9461 & 0.9357 \\
\hline \multirow{7}{*}{ DAE vs } & $\mathrm{SH}$ & 0.5162 & 0.8002 \\
\hline & SBD & 0.7726 & 0.8846 \\
\hline & NL & 0.1824 & --- \\
\hline & SBDM & 0.6975 & 0.8378 \\
\hline & LDM & 0.5880 & 0.8382 \\
\hline & $\mathrm{RDM}$ & 0.8135 & 0.8650 \\
\hline & TDM & 0.6939 & 0.8727 \\
\hline \multirow{6}{*}{$\mathrm{SH}$ vs } & SBD & 0.7176 & 0.7674 \\
\hline & NL & 0.4703 & --- \\
\hline & SBDM & 0.8112 & 0.7830 \\
\hline & LDM & 0.7346 & 0.8140 \\
\hline & $\mathrm{RDM}$ & 0.7111 & 0.7509 \\
\hline & TDM & 0.7741 & 0.8100 \\
\hline \multirow{5}{*}{ SBD vs } & NL & 0.2946 & --- \\
\hline & SBDM & 0.8033 & 0.8943 \\
\hline & LDM & 0.7372 & 0.8522 \\
\hline & $\mathrm{RDM}$ & 0.8382 & 0.8722 \\
\hline & TDM & 0.8084 & 0.8896 \\
\hline \multirow{4}{*}{ NL vs } & SBDM & 0.5643 & --- \\
\hline & LDM & 0.5811 & --- \\
\hline & $\mathrm{RDM}$ & 0.3569 & --- \\
\hline & TDM & 0.5432 & --- \\
\hline \multirow{3}{*}{ SBDM vs } & LDM & 0.9010 & 0.9001 \\
\hline & RDM & 0.8740 & 0.8674 \\
\hline & TDM & 0.9508 & 0.9259 \\
\hline \multirow{2}{*}{ LDM vs } & $\mathrm{RDM}$ & 0.8247 & 0.9149 \\
\hline & TDM & 0.9789 & 0.9848 \\
\hline RDM vs & TDM & 0.9167 & 0.9681 \\
\hline
\end{tabular}

Cerne, Lavras, v. 16, n. 4, p. 457-464, out./dez. 2010 
Table 2 - Direct and indirect effects and coefficient of determination $\left(\mathrm{R}^{2}\right)$, obtained by using path analysis between the Dickson quality index and other observed variables in seedlings of Eucalyptus grandis and Pinus elliottii. Santa Maria, RS, 2009.

Tabela 2 - Efeitos direto e indireto e coeficiente de determinação $\left(R^{2}\right)$ obtidos pela análise de trilha entre o Índice de Qualidade de Dickson e as demais variáveis observadas em mudas de Eucalyptus grandis e Pinus elliottii. Santa Maria, RS, 2009.

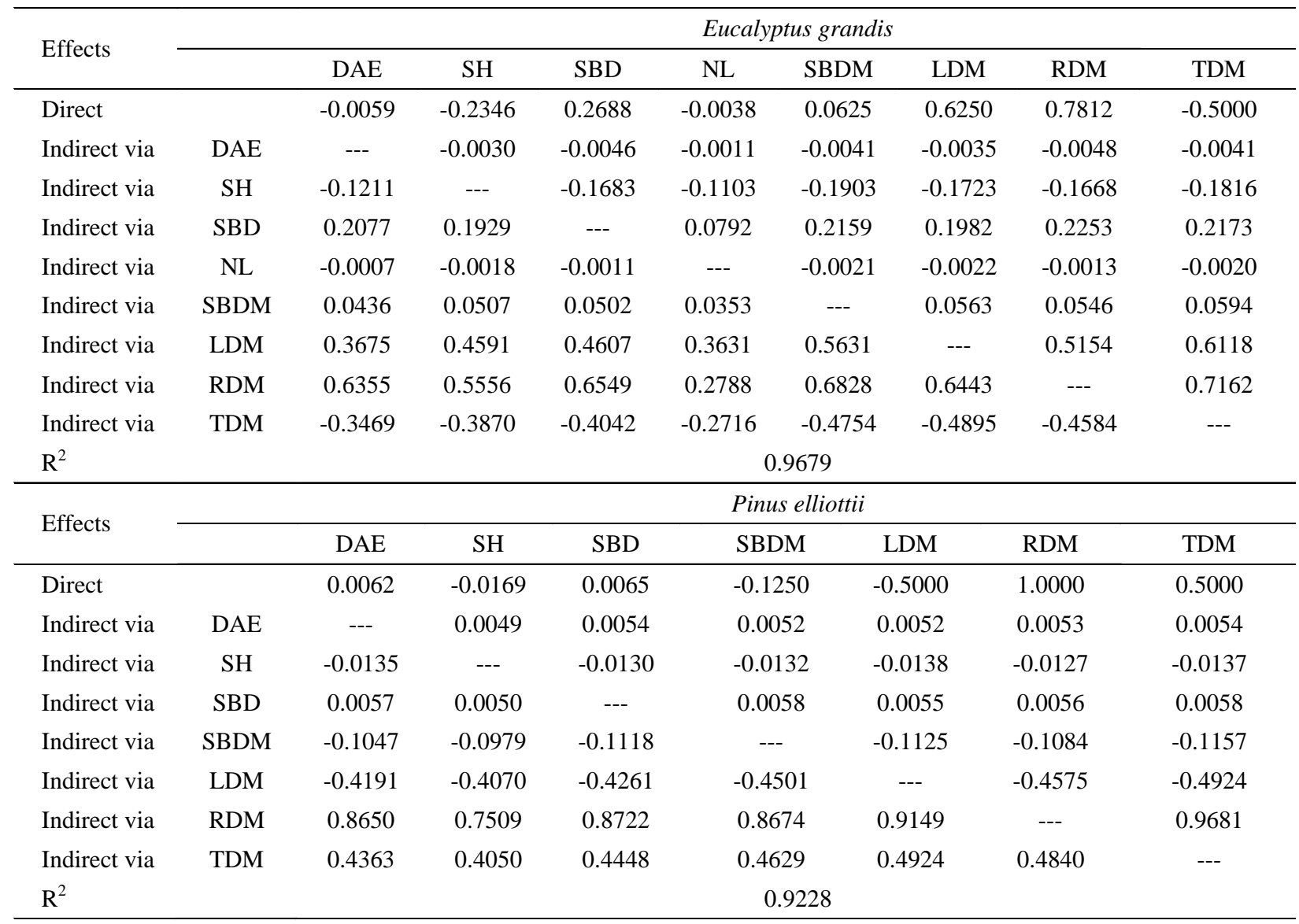

(Table 3), with independent variables DAE and SBD and $\mathrm{R}^{2}{ }_{\mathrm{aj}}=0.8025$, very close to the highest scoring equation E6, with $\mathrm{R}^{2}{ }_{\text {aj }}=0.8248$. However, E6 includes variable NL. Models suggested as second and third best scoring models - E1 and E5 respectively - also include SH. It is thus suggested that model E2 be selected for the reason that, among the four best scoring models, it is the easiest to obtain and because its $\mathrm{R}^{2} \mathrm{aj}, \mathrm{CV} \%$ and Syx values are very close to the highest scoring model $(\mathrm{E} 6=39)$.

Model E11, in which DAE individually explains DQI, is not suggested, as it comes last but one in scoring, reinforcing the fact that DAE can be accepted along with SBD as an independent variable to explain DQI. Also, $\mathrm{SH}$ as an independent variable to individually explain DQI (model
E12) showed the poorest score out of the 13, it being a great risk to use it individually to explain DQI. To a certain degree, this result relates to assertions made by Gomes \& Paiva (2004), who reported that using shoot height as sole criterion to evaluate seedling quality in forest species can prove deficient where a high performance is expected from them.

As regards $P$. elliottii, the best scoring model, P3, is related to independent variables DAE and SBD and is considered one of the easiest to obtain (Table 3). According to Gomes \& Paiva (2004), stem base diameter, being easily measurable, is considered by many researchers a critical parameter for estimating field survival of forest seedlings. According to these authors, in several forest species, the quality standard of seedlings ready for planting has a high correlation with said parameter, and that can be verified by

Cerne, Lavras, v. 16, n. 4, p. 457-464, out./dez. 2010 
Table 3 - Coefficients of variation $(C V \%)$ and adjusted determination $\left(\mathrm{R}^{2} \mathrm{aj}\right)$, standard deviation (Syx) of equations between observed variables in seedlings of Eucalyptus grandis and Pinus elliottii. Santa Maria, RS. 2009.

Tabela 3 - Coeficientes de variação (CV\%) e de determinação ajustado ( $\left.R^{2} a j\right)$, desvio padrão (Syx) das equações entre variáveis observadas em mudas de Eucalyptus grandis e Pinus elliottii. Santa Maria, RS. 2009.

\begin{tabular}{|c|c|c|c|c|c|c|c|}
\hline \multirow{2}{*}{ Equations } & \multirow{2}{*}{$\mathrm{CV} \%$} & \multirow{2}{*}{$R^{2} a j$} & \multirow{2}{*}{ Syx } & \multicolumn{3}{|c|}{ Criterion } & \multirow{2}{*}{ Sum of scores } \\
\hline & & & & $\mathrm{CV} \%$ & $\mathrm{R}^{2} \mathrm{aj}$ & Syx & \\
\hline \multicolumn{8}{|c|}{ Eucalyptus grandis } \\
\hline E1 & 23.68 & 0.8237 & 0.00735 & 12 & 12 & 12 & 36 \\
\hline $\mathrm{E} 2$ & 25.06 & 0.8025 & 0.00778 & 10 & 10 & 10 & 30 \\
\hline E3 & 30.30 & 0.7114 & 0.00941 & 4 & 4 & 5 & 13 \\
\hline $\mathrm{E} 4$ & 31.33 & 0.6914 & 0.00973 & 3 & 3 & 4 & 10 \\
\hline E5 & 24.96 & 0.8041 & 0.00775 & 11 & 11 & 11 & 33 \\
\hline E6 & 23.61 & 0.8248 & 0.00733 & 13 & 13 & 13 & 39 \\
\hline E7 & 29.40 & 0.7283 & 0.00913 & 5 & 5 & 6 & 16 \\
\hline E8 & 27.09 & 0.7693 & 0.03766 & 6 & 6 & 1 & 13 \\
\hline E9 & 26.02 & 0.7871 & 0.00808 & 9 & 9 & 9 & 27 \\
\hline E10 & 26.08 & 0.7860 & 0.00810 & 8 & 8 & 8 & 24 \\
\hline E11 & 34.26 & 0.6309 & 0.01064 & 2 & 2 & 3 & 7 \\
\hline E12 & 42.71 & 0.4263 & 0.01326 & 1 & 1 & 2 & 4 \\
\hline E13 & 27.08 & 0.7694 & 0.00840 & 7 & 7 & 7 & 21 \\
\hline \multicolumn{8}{|c|}{ Pinus elliottii } \\
\hline $\mathrm{P} 1$ & 59.50 & 0.4971 & 0.07201 & 1 & 1 & 1 & 3 \\
\hline $\mathrm{P} 2$ & 41.26 & 0.7582 & 0.04995 & 6 & 6 & 6 & 18 \\
\hline P3 & 41.13 & 0.7597 & 0.04980 & 7 & 7 & 7 & 21 \\
\hline P4 & 44.93 & 0.7132 & 0.05440 & 2 & 2 & 2 & 6 \\
\hline P5 & 44.37 & 0.7204 & 0.05372 & 4 & 4 & 4 & 12 \\
\hline P6 & 44.86 & 0.7175 & 0.05431 & 3 & 3 & 3 & 9 \\
\hline P7 & 43.91 & 0.7261 & 0.05316 & 5 & 5 & 5 & 15 \\
\hline
\end{tabular}

E1) $\mathrm{DQI}=-0.0410+0.00025 * \mathrm{dae}+0.00034 * \mathrm{sbd}-0.000094 * \mathrm{sh}+0.00044 * \mathrm{n} 1$

E2) DQI $=-0.0388+0.00024 *$ dae $+0.37435 * \mathrm{sbd}$

E3) $\mathrm{DQI}=-0.0395+0.00051 * \mathrm{dae}+0.00341 * \mathrm{sh}$

E4) $\mathrm{DQI}=-0.0333+0.000617 *$ dae $+0.000689 * \mathrm{nl}$

E5) $\mathrm{DQI}=-0.0404+0.000246 * \mathrm{dae}+0.33969 * \mathrm{sbd}+0.000782 * \mathrm{sh}$

E6) $\mathrm{DQI}=-0.0412+0.000255 * \mathrm{dae}+0.33953 * \mathrm{sbd}+0.000433 * \mathrm{nl}$

E7) $\mathrm{DQI}=-0.0400+0.000523 * \mathrm{dae}+0.00261 * \mathrm{sh}+0.00042 * \mathrm{nl}$

E8) $\mathrm{DQI}=-0.0349+0.48164 * \mathrm{sbd}+0.000542 * \mathrm{sh}$

E9) $\mathrm{DQI}=-0.0357+0.47910 * \mathrm{sbd}+0.000392 * \mathrm{nl}$

E10) $\mathrm{DQI}=-0.0353+0.48934 * \mathrm{sbd}-0.000288 * \mathrm{sh}+0.00041 * \mathrm{nl}$

E11) $\mathrm{DQI}=-0.0279+0.00065 *$ dae

E12) $\mathrm{DQI}=-0.0168+0.0067 * \mathrm{sh}$

E13) $\mathrm{DQI}=-0.0339+0.5034 * \mathrm{sbd}$

P1) DQI $=-0.1475+0.0282 *$ sh

P2) $\mathrm{DQI}=-0.126+0.00086519 * \mathrm{dae}+0.00108 * \mathrm{sbd}+0.000320 * \mathrm{sh}$

P3) DQI $=-0.125+0.000874 *$ dae $+0.00109 *$ sbd

P4) DQI $=-0.050+0.00171 *$ dae

P5) $\mathrm{DQI}=-0.167+0.00198 * \mathrm{sbd}$

P6) $\mathrm{DQI}=-0.069+0.00157 * \mathrm{dae}+0.00340 * \mathrm{sh}$

P7) $\mathrm{DQI}=-0.183+0.00174 * \mathrm{sbd}+0.00535 * \mathrm{sh}$

Cerne, Lavras, v. 16, n. 4, p. 457-464, out./dez. 2010 
significant increases in survival and growth rates of plants out in the field.

The second best scoring model had $\mathrm{SH}$ added, in agreement with Gomes et al. (2002), suggesting that SBD, whether measured in isolation or in combination with $\mathrm{SH}$, was an important morphological trait to predict seedling quality in forest species. It should be noted that SBD appears as independent variable in all four best scoring models, it being of great importance, as with E. grandis, disregarding plant matter. The reliability of DAE in isolation to explain DQI is poor, as model P4 obtained the second lowest score. In analyzing model P1 (Table 3), SH proved unreliable to explain DQI, as this model obtained the lowest score, similarly to E. grandis.
In comparing the effects of different competition types, best model fits were obtained for varied competition, irrespective of the species (Table 4). This can be explained by the fact that varied competition allows more room between seedlings throughout the development cycle, allowing better light absorption than full competition and favoring more evenly distributed diameters.

As for SH in full competition, seedlings tended to show an irregular growth pattern while striving for light absorption, and this behavior caused them to differ, with sturdier seedlings outstripping weaker ones, characterizing dissimilar behavior in comparison to varied competition, in both species. This result can be confirmed by observing that in both species the analysis of height in full competition derived a smaller $\mathrm{R}^{2}$ value and a

Table 4 - Coefficient of determination $\left(\mathrm{R}^{2}\right)$ and standard deviation (Syx) of equations between observed variables in seedlings of Eucalyptus grandis and Pinus elliottii, for each competition type. Santa Maria, RS. 2009.

Tabela 4 - Coeficiente de determinação $\left(R^{2}\right)$ e desvio padrão (Syx) das equações entre as variáveis observadas em mudas de Eucalyptus grandis e Pinus elliottii com diferentes níveis de competição. Santa Maria, RS. 2009.

\begin{tabular}{|c|c|c|}
\hline \multicolumn{3}{|c|}{ Eucalyptus grandis } \\
\hline & Full competition & Varied competition \\
\hline & $\mathrm{NL}=13.30+0.01 \mathrm{DAE}$ & $\mathrm{NL}=7.32+0.06 \mathrm{DAE}$ \\
\hline $\mathrm{R}^{2}$ & 0.0046 & 0.0388 \\
\hline \multirow[t]{2}{*}{ Syx } & 5.76 & 6.05 \\
\hline & $\mathrm{SBD}=35.23+1.05 \mathrm{DAE}$ & $\mathrm{SBD}=22.00+1.17 \mathrm{DAE}$ \\
\hline $\mathrm{R}^{2}$ & 0.4716 & 0.5879 \\
\hline \multirow[t]{2}{*}{ Syx } & 23.55 & 19.97 \\
\hline & $\mathrm{SH}=2.82+0.05 \mathrm{DAE}$ & $\mathrm{SH}=2.65+0.05 \mathrm{DAE}$ \\
\hline $\mathrm{R}^{2}$ & 0.2310 & 0.3029 \\
\hline Syx & 1.90 & 1.49 \\
\hline \multicolumn{3}{|c|}{ Pinus elliottii } \\
\hline & Full competition & Varied competition \\
\hline & $\mathrm{SBD}=78.02+0.69 \mathrm{DAE}$ & $\mathrm{SBD}=70.23+0.75 \mathrm{DAE}$ \\
\hline $\mathrm{R}^{2}$ & 0.7662 & 0.7736 \\
\hline \multirow[t]{2}{*}{ Syx } & 19.11 & 19.35 \\
\hline & $\mathrm{SH}=5.53+0.456 \mathrm{DAE}$ & $\mathrm{SH}=4.78+0.049 \mathrm{DAE}$ \\
\hline $\mathrm{R}^{2}$ & 0.2009 & 0.6408 \\
\hline Syx & 3.93 & 1.39 \\
\hline
\end{tabular}

Cerne, Lavras, v. 16, n. 4, p. 457-464, out./dez. 2010 
higher Sxy value than in varied competition, indicating greater variability in growth pattern.

The correlation of SBD with DAE was better evidenced with estimations from linear equations for the relevant species (Table 4), which, in comparison to other equations, having height and number of leaves as dependent variables, in eucalyptus, those correlating SBD with DAE showed best fittings. This indicates that, in order to verify the degree of seedling quality, stem base diameter is the non-destructive testing variable that best expresses this characteristic, in other words, the larger the diameter, the greater the shoot dry matter volume and the higher the DQI value, indicating better quality.

\section{CONCLUSIONS}

Dry matter variables are the most strongly correlated with the Dickson quality index (DQI), followed by stem base diameter.

Number of leaves is the variable showing the poorest correlation with DQI, followed by seedling height.

\section{ACKNOWLEDGMENTS}

The authors wish to thank $\mathrm{CNPq}$ for granting scholarships for research accomplishment.

\section{BIBLIOGRAPHICAL REFERENCES}

CRUZ, C. D.; CARNEIRO, P. C. S. Modelos biométricos aplicados ao melhoramento genético. Viçosa, MG: UFV, 2003. $585 \mathrm{p}$.

DANIEL, O. et al. Aplicação de fósforo em mudas de Acacia mangium. Revista Árvore, Viçosa, v. 21, n. 2, p. 163-168, 1997.

DICKSON, A.; LEAF, A. L.; HOSNER, J. F. Quality appraisal of white spruce and white pine seedling stock in nurseries. Forestry Chronicle, v. 36, p. 10-13, 1960.

FONSECA, E. P. et al. Padrão de qualidade de mudas de Trema micrantha (L.) Blume, produzidas sob diferentes períodos de sombreamento. Revista Árvore, Viçosa, v. 26, n. 4, p. 515-523, 2002.
GOMES, J. M. et al. Parâmetros morfológicos na avaliação da qualidade de mudas de Eucalyptus grandis. Revista Árvore, Viçosa, v. 26, n. 6, p. 655-664, 2002.

GOMES, J. M.; PAIVA, H. N. Viveiros florestais: propagação sexuada. 3. ed. Viçosa, MG: UFV, 2004. 116 p.

HERMANN, R. K. Importance of top-root ratios for survival of Douglas-fir seedlings. Tree Planters' Notes, v. 64, p. 7$11,1964$.

JOHNSON, J. D.; CLINE, M. L. Seedling quality of southern pines. In: DURYEA, M. L.; DOUGHERTY, P. M. (Eds.). Forest regeneration manual. Netherlands: Klumer Academic, 1991. p. 143-162.

JOSÉ, A. C.; DAVIDE, A. C.; OLIVEIRA, S. L. Produção de mudas de aroeira (Schinus terebinthifolius raddi) para recuperação de áreas degradadas pela mineração de bauxita. Cerne, Lavras, v. 11, n. 2, p. 187-196, 2005.

PAIVA, H. N.; GOMES, J. M. Viveiros florestais. Viçosa, MG: UFV, 1993. 56 p.

PARVIAINEM, J. V. Qualidade e avaliação de mudas florestais. In: SEMINÁRIO DE SEMENTES E VIVEIROS FLORESTAIS, 1., 1981, Curitiba. Anais... Curitiba: FUPEF, 1981. p. 59-90.

REIS, E. R. et al. Período de permanência de mudas de Eucalyptus grandis em viveiro baseado em parâmetros morfológicos. Revista Árvore, Viçosa, v. 32, n. 5, p. 809-814, 2008a.

REIS, E. R. et al. Variabilidade dos parâmetros morfológicos em mudas de Pinus elliottii Engelm. Cerne, Lavras, v. 14, n. 2, p. 141-146, 2008b.

WENDLING, I.; PAIVA, H. N.; GONÇALVEZ, W. Técnicas de produção de mudas de plantas ornamentais. Viçosa, MG: Aprenda Fácil, 2005. v. 3, 203 p. 